\title{
Pengembangan Instrumen Penilaian Sikap Sosial Aspek Tanggung Jawab Pembelajaran Tematik Terpadu Siswa Kelas 4 SD
}

\author{
Khanifatul Safitri ${ }^{1 *}$, Nyoto Hariono \\ ${ }^{1}$ Universitas Kristen Satya Wacana, \\ Salatiga, Indonesia, \\ *e-mail: khanifatulsafitri@gmail.com
}

\begin{abstract}
Abstrak
Pada Kurikulum 2013 penilaian dalam pembelajaran sekolah dasar mencakup tiga ranah pembelajaran yaitu sikap, pengetahuan dan keterampilan. Fokus pada penilaian sikap pada pembelajaran yang dirasa masih kurang tepat. Hal tersebut dapat diketahui berdasarkan pengamatan yang telah dilakukan selama penelitian bahwa guru dalam melakukan penilaian sikap hanya melalui observasi selama proses pembelajaran. Untuk itu instrumen penilaian sikap perlu dikembangkan. Penelitian pengembangan ini bertujuan untuk menghasilkan instrument penilaian sikap sosial yang valid khususnya pada aspek tanggung jawab. Produk ini penting untuk dikembangkan supaya dapat mengetahui tingkat perkembangan sikap tanggung jawab peserta didik. Metode penelitian yang digunakan yaitu jenis penelitian RND (Research and Development) dengan model penelitian ADDIE (Analysis, Design, Development, Implementasi, Evaluation). Sample dalam penelitian ini menggunakan subjek peserta didik kelas 4 yang secara keseluruhan berjumlah 15 responden. Dari uji coba terbatas didapatkan bahwa dari 40 butir pernyataan yang diujicobakan, 12 (30\%) butir pernyataan memiliki tingkat validitas sangat tinggi, 14 (35\%) butir pernyataan memiliki tingkat validitas tinggi, $12(32,5 \%)$ butir pernyataan memiliki tingkat validitas cukup, $1(27,5 \%)$ butir pernyataan memiliki tingkat validitas rendah dan memiliki rata-rata rhitung sebesar $0,671 \geq 0,20$ maka instrumen dinyatakan valid. Sedangkan reliabilitas pada uji terbatas diperoleh $\alpha$ sebesar 0.970 dengan kriteria sangat reliabel. Berdasarkan hasil penelitian tersebut dapat disimpulkan bahwa instrument penilaian sikap sosial aspek tanggung jawab pada pembelajaran tematik terpadu kelas 4 layak untuk digunakan.
\end{abstract}

Kata kunci: instrumen penilaian, sikap sosial, tanggung jawab

\begin{abstract}
Curriculum 2013 (Curriculum 2013) primary school curriculum three learning domains, namely attitudes, knowledge, and skills. Focus on providing attitudes to learning that are deemed inappropriate. This can be seen based on observations made during the study that the teacher takes measurements based on observations during the learning process. For that, an attitude assessment needs to be developed. This development research aims to produce valid responsibility instruments, especially in the aspect of responsibility. This product is important to develop together, it can be seen from the level of responsibility of students. The research method used is the type of research RND (Research and Development) with the ADDIE research model (Analysis, Design, Development, Implementation, Evaluation). The research sample used the subject of grade 4 students in total in 15 respondents. From the limited trial, it was found that of the 40 items tested, 12 (30\%) statement items had a very high validity level, 14 (35\%) statement items had a high validity level, 12 (32.5\%) items had a validity level. Enough, $1(27.5 \%)$ item stated that it had a low level of validity and had an average count of $0.671 \geq 0.20$, so the instrument was declared valid. While the reliability in the limited test obtained $\alpha$ of 0.970 with very reliable criteria. Based on the results of this study, it can be seen that the responsibility aspect social assessment instrument in integrated thematic learning in class 4 is feasible to use..
\end{abstract}

Keywords: assessment instruments, social attitudes, responsibility aspects 


\section{Pendahuluan}

Penilaian dan pembelajaran adalah dua hal yang tidak bisa dipisahkan. Dengan adanya penilian maka guru akan tahu seberapa berhasil pembelajaran yang dilakukan. Efektifitas pembelajaran dipengaruhi oleh bagaimana penilain yang dilakukan, dengan adanya hasil penilain dari proses pembelajaran pendidik akan mampu mengelola pembelajaran dengan baik (Msosa et al., 2021; Tridane et al., 2015; Uttl, B., White \& Gonzalez, 2017). Selain itu, sangat penting bagi peserta didik dapat melakukan penilain terhadap apa yang mereka pelejari serta ini akan berdampak terhadap kepercayaan diri dan motivasinya dalam proses belajar (Carpenter et al., 2020), Penilaian akan memberikan pilihan kepada peserta didik untuk belajar atau tidak belajar (Saenz \& Smith, 2018). Dengan kata lain, adanya assessment yang dilakukan oleh pengajar akan berdampak terhadap siswa karena memberikan umpan balik dari apa yang sudah dibelajari oleh siswa (Granberg et al., 2021). Penilain yang baik adalah penilain yang dilakukan secara menyeluruh menyangkut sikap, keterampilan dan pengetahuan peserta didik (Machts et al., 2020; Riscaputantri \& Wening, 2018). Salah satu penilaian yang dilakukan adalah penilian sikap. Penilaian sikap berhubungan dengan sikap siswa terhadap materi pelajaran, sikap siswa terhadap guru/pengajar, sikap siswa terhadap proses pembelajaran, dan sikap yang berkaitan dengan nilai atau norma yang berhubungan dengan materi pembelajaran (Ulfa, 2019). Penilaian sikap yang dilakukan oleh guru biasanya melalui pengamatan secara langsung (observasi), penilaian diri, dan penilaian daftar cek atau skala penilaian antar peserta didik yang disertai dengan rubrik (Delita, 2017). Jadi, penilaian sikap akan memberikan gambaran tentang bagaiman sikap anak dalam menghadapi proses pembelajaran.

Namun, berdasarkan hasil pengamatan di SD Negeri Sambirejo 02, SD Negeri Pringapus 02, dan SD Negeri Pringapus 03 memperoleh informasi bahwa dalam pembelajaran guru telah melakukan penilaian terhadap peserta didik berdasarkan pengamatan selama proses pembelajaran dan menggunakan rubrik penilaian yang ada di buku Guru. Guru kesulitan dalam menyusun instrument penilaian sikap khususnya aspek tanggung jawab peserta didik karena tidak mengetahui seperti apa format penilaian sikap yang baik. Sebelum pembutan instrumen penilaian, guru tidak membuat kisi-kisi instrumennya terlebih dahulu sehingga guru kurang memiliki acuan sejak awal. Dari pengamatan yang sudah dilakukan juga guru belum memiliki instrumen penilaian sikap tanggung jawab yang baik dan instrumen sikap tanggung jawab yang sudah ada, belum pernah diujicobakan dan belum pernah diketahui validitas dan reliabilitasnya. Penilaian sikap yang dilakukan oleh guru biasanya melalui pengamatan secara langsung (observasi), penilaian diri, dan penilaian daftar cek atau skala penilaian antar peserta didik yang disertai dengan rubrik. Hambatan lainnya guru tidak melakukan penilaian sikap adalah karena sebagian besar guru belum paham cara membuat instrumen dan cara melakukan penilaian sikap (Kartowagiran \& Jaedun, 2016). Guru hanya membuat tabelnya saja dan menilai siswa berdasarkan pengamatan tanpa berpedoman dengan rubrik (Muslimah et al., 2017; Wicaksono et al., 2016). Penilaian yang dilakukan guru belum sesuai dengan penilaian autentik karena masih ditekankan pada penilaian hasil belajar kognitif, sedangkan penilaian proses pembelajaran dilakukan hanya secara umum saja tanpa menggunakan instrumen penilaian (Sa'adah \& Sigit, 2018). Jadi, penilaian sikap masih belum dapat dilaksankan secara optimal mengingat guru masih belum mampu membuat dan mengaplikasikan penilian sikap. Jika hal ini dibiarkan akan berdampak buruk terhadap pembentukan sikap anak dalam proses pembelajaran. Kurangnya sikap sosial peserta didik didalam kelas saat berlangsungnya pembelajaran seperti kurang disiplin dalam mengerjakan tugas, dan kurang santun saat berbicara masih menggunakan bahasa yang kasar. Hal ini terjadi salah satunya karena belum adanya umpan balik yang jelas tentang bagaimana sikap siswa.

Mengatasi masalah tersebut, salah satu solusi yang bisa dilakukan adalah dengan mengembangkan instrumen penilaian sikap. Instrumen adalah alat yang digunakan untuk mengukur sikap siswa (Astalini \& Kurniawan, 2019). Dalam mengembangkan instrument yang perlu dibuat adalah kisi-kisi instrumen. Beberapa penelitian yang 
sudah dilakukan berkaitan dengan pengembangan instrument sikap adalah penelitian yang dilakukan oleh Wicaksono et al., (2016) menghasilkan instrumen penilaian sikap dengan teknik observasi, self assessment, dan peer assessment yang valid dan reliabel digunakan. Muslimah et al., (2017) menghasilkan instrumen penilaian sikap berupa rubrik penilaian sikap sosial pada outdoor learning yang layak digunakan setelah dilakukan uji validas, reliabitas, uji kelayakan dan uji coba. Astalini \& Kurniawan, (2019) menghasilkan instrument penilan sikap siswa terhadap mata pelajaran IPA yang valid dan reliabel. Berdasarkan hasil penelitian yang dilakukan instrumen penilaian yang dihasilkan masih umum, belum secra khusus. Oleh sebab itu penelitian ini akan mengembangkan penilaian sikap instrumen penilaian sikap tanggung jawab pembelajaran tematik terpadu.

Tujuan penelitian ini adalah untuk menghasilkan instrument penilaian sikap sosial yang valid khususnya pada aspek tanggung jawab. Degan adanya instrument penilaian sikap kususnya aspek tanggung jawab memberikan salah satu alat yang digunaka untuk mengukur sikap tanggungjawab siswa. Adanya instrumen yang dikembangkan memberikan umpan balik terhadap disikap tanggungjawab siswa. hal ini akan membantu siswa dalam mengembangkan sikap tanggungjawab.

\section{Metode}

Penelitian pengembangan ini menggunakan jenis penelitian pengembangan atau $R \& D$ (Research and Development). Desain dan pengembangan instrumen penialian sikap sosial aspek tanggung jawab disusun sesuai dengan model pengembangan ADDIE. Langkah-langkah 1) Analysis; 2) Design; 3) Development; 4) Implementation; dan 5) Evaluation yang dapat dilihat pada gambar 1 berikut. Subjek dalam penelitian ini adalah siswa kelas 4 yang dilakukan di SD Negeri Pringapus 02, SD Negeri Pringapus 03 dan SD Negeri Sambirejo 02 untuk melihat validitas dan reliabilitas instrumen penilaian sikap sosial aspek tanggung jawab. Dalam penelitian ini teknik pengumpulan data dengan menggunakan angket. Angket ini akan diisi oleh ahli penilaian, ahli materi, dan ahli Bahasa yang akan digunakan untuk memvalidasi butir pernyataan pada angket instumen penilaian sikap sosial aspek tanggung jawab peserta didik. Uji validasi ahli bertujuan untuk mengetahui apakah instrument penilaian yang dikembangkan sudah layak digunakan atau belum layak digunakan.

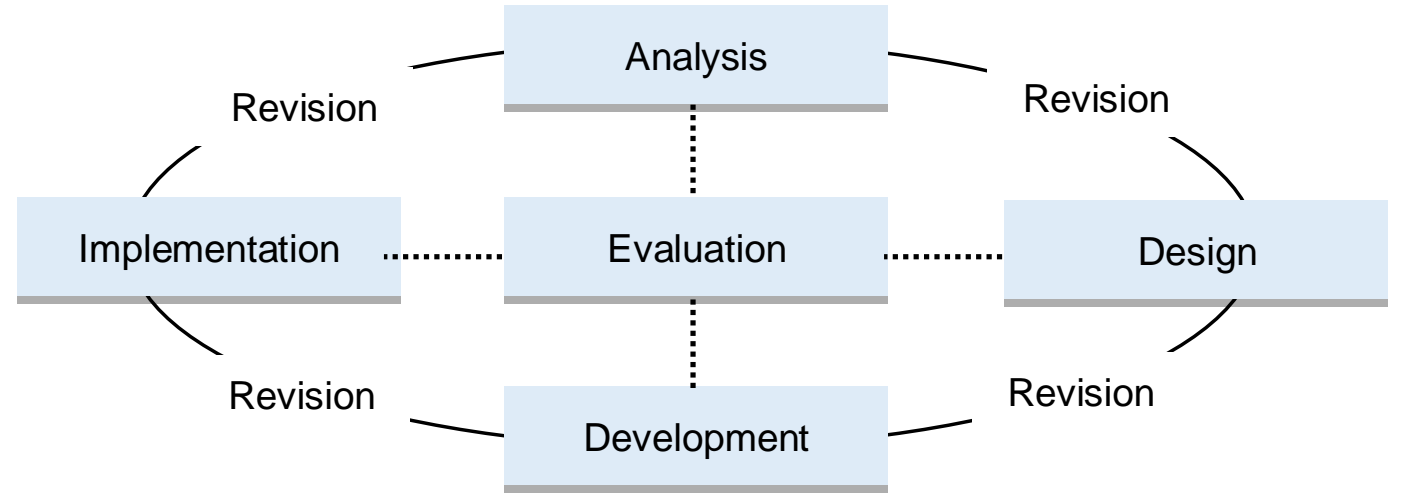

Gambar 1. Model Pengembangan ADDIE

Secara sederhana tahap penelitian ini adalah analysis, Tahap ini dilakukan dengan melakukan observasi atau survey di SD Negeri Pringapus 02, SD Negeri Pringapus 03, dan SD Negeri Sambirejo 02 terkait dengan pelaksanaan penilaian sikap sosial aspek tanggung jawab. Serta kajian dalam mengembangan instrument penilaian sikap sosial aspek tanggung jawab dilakukan dengan mengumpulkan data informasi 
tentang tahap-tahapan mengembangkan instrument penilaian sikap sosial. Design pada tahap ini akan dilakukan pembuatan kisi-kisi instrument penilaian sikap aspek tanggungjawab pada pembelajaran tematik terpadu kelas 4 tema 7 Indahnya Keragaman di Negeriku subtema 1 Keragaman Suku Bangsa dan Agama di Negeriku semester 2.

Development, pada tahap pengembangan produk instrumen melalui dua tahapan. Tahapan yang pertama pengembangan instrumen penilaian sikap tanggung jawab pembelajaran tematik terpadu dan yang kedua uji validitas produk pengembangan instrumen penilaian sikap tanggung jawab pembelajaran tematik terpadu. Tahap mengambangkan instrumen penilaian sikap sosial aspek tanggung jawab pada butir-butir pernyataan menggunakan Skala Likert kedalam angket sesuai dengan indikator yang akan dikembangkan. Pengembangan instrument penilaian sikap sosial aspek tanggung jawab ini, disusun ke dalam 40 butir pernyataan. Produk instrument penilaian sikap sosial yang dikembangkan terdiri dari 20 pernyataan favorable dan 20 pernyataan unfavorable. Instrumen penilaian sikap sosial yang telah disusun kemudian divalidasi oleh ahli, yaitu ahli penilaian, ahli materi, dan ahli Bahasa. Peneliti juga menyusun angket instrument penilaian ahli penilaian sikap, ahli materi, dan ahli Bahasa yang akan digunakan untuk memvalidasi butir pernyataan pada angket instumen penilaian sikap sosial aspek tanggung jawab peserta didik.

Implementation, produk yang telah dikembangkan kemudian diimplementasikan secara uji terbatas. Produk yang telah divalidasi oleh ahli dan diperbaiki kemudian diujicobakan secara terbatas dilakukan dengan memberikan angket instrumen penilaian penilaian sikap sosial aspek tanggung jawab sejumlah 15 peserta didik dari SD Negeri Pringapus 02, SD Negeri Pringapus 03, dan SD Negeri Sambirejo 02. Evaluation, pada tahap terakhir yaitu tahap evaluasi, melakukan analisis dan memperbaiki atau revisi pada produk yang sudah divalidasi oleh ahli dan produk yang sudah diujicobakan.

Hasil uji coba merupakan data kuantitatif yang kemudian dianalisis sesuai dengan tujuan penelitian dan pengembangan yang akan dicapai, sehingga data akhir yang diperoleh dapat digunakan pada pengembangan produk. Apabila hasil analisis tidak valid, maka tidak perlu dilakukan revisi sesuai dengan saran dan rekomedasi ahli. Untuk mengetahui tingkat validitas instrument penilaian sikap sosial aspek tanggung jawab dapat menggunakan rumus korelasi pearson product moment yang diperoleh melalui IBM SPSS 25. Hasil uji validasi ahli dianalisis dengan teknik deskriptif dan persentase untuk mengetahui tingkat validitas instrumen penilaian karakter yang telah dibuat. Persentase yang diperoleh dapat dikelompokkan dengan rentang indeks validitas secara inci disajikan dalam tabel 1 berikut.

\begin{tabular}{ccc} 
& \multicolumn{2}{c}{ Tabel 1. Rentang Indeks Validitas } \\
\hline No. & Indeks & Interpretasi \\
\hline 1 & $0,81-1,00$ & Sangat tinggi \\
2 & $0,61-0,80$ & Tinggi \\
3 & $0,41-0,60$ & Cukup \\
4 & $0,21-0,40$ & Rendah \\
5 & $0,00-0,20$ & Sangat rendah \\
\hline & & Sumber: Wardani $(2012: 344)$
\end{tabular}

Sedangkan untuk mengetahui reliabilitas dari instrument penilaian yang dikembangkan, dapat dilihat dari keajegan pada hasil penelitian yang telah dilaksanakan. Reliabilitas dapat diukur dari tiga kriteria yaitu: (1) stability (keajegan) berhubungan dengan kriteria yang memperlihatkan keajegan hasil yang ditunjukkan alat ukur dalam mengukur butir tes yang sama walaupun dilakukan pada waktu yang berbeda. (2) Dependability (kemantapan) yaitu kemantapan alat ukur dapat diandalkan dalam mengukur butir tes. (3) Predictability (dapat diramalkan) yaitu saling berkaitan dan berkesinambungan. Klasifikasi indeks reliabilitas dirinci melalui tabel 2 berikut ini. 
Tabel 2. Indeks Reliabilitas

\begin{tabular}{ccc}
\hline No. & Indeks & Interpretasi \\
\hline 1 & $0,80-1,00$ & Sangat reliabel \\
2 & $<0,80-0,60$ & Realiabel \\
3 & $<0,60-0,40$ & Cukup reliabel \\
4 & $<0,40-0,20$ & Agak reliabel \\
5 & $<0,20$ & Kurang reliabel \\
\hline & & Sumber: Wardani $(2012: 344)$.
\end{tabular}

\section{Hasil dan Pembahasan Hasil Penelitian}

Hasil studi pendahuluan menghasilkan bahan dasar tentang sikap sosial dengan aspek tanggung jawab yang akan digunakan untuk menyusun draf produk instrumen penilaian sikap tanggung jawab pada pembelajaran tematik terpadu. Tahap studi pendahuluan dilakukan dengan melakukan observasi atau survey di SD Negeri Pringapus 02, SD Negeri Pringapus 03, dan SD Negeri Sambirejo 02 terkait dengan pelaksanaan penilaian sikap sosial aspek tanggung jawab. Kajian dalam mengembangan instrument penilaian sikap sosial aspek tanggung jawab dilakukan dengan mengumpulkan data informasi tentang tahap-tahapan mengembangkan instrument penilaian sikap sosial. Dari hasil observasi dan wawancara ditemukan bawah selama ini guru belum memiliki instrumen penilaian sikap tanggung jawab yang baik dan instrumen sikap tanggung jawab yang sudah ada, belum pernah diujicobakan dan belum pernah diketahui validitas dan reliabilitasnya. Penilaian sikap yang dilakukan oleh guru biasanya melalui pengamatan secara langsung (observasi), penilaian diri, dan penilaian daftar cek atau skala penilaian antar peserta didik yang disertai dengan rubrik. Sehingga guru kesulitan dalam menilai sikap sosial aspek khususnya aspek tanggung jawab siswa dalam proses belajar.

\section{Analysis (Analisis)}

Pada tahap awal peneliti melakukan observasi dan wawancara kepada guru SD kelas IV. Hasil observasi dan wawancara menyatakan bahwa guru belum memiliki instrument penilaian sikap sosial aspek tanggung jawab yang baik, instrument sikap sosial aspek tanggung jawab yang sudah ada, belum pernah diujicobakan dan belum pernah diketahui validitas dan reliabilitasnya. Hasil penelitian dan pengembangan tentang isntrumen penilaian sikap sosial aspek tanggung jawab pada pembelajaran tematik terpadu di SD masih terbatas.

\section{Design (Perancangan)}

Setelah melakukan tahap analisis, tahap kedua yaitu merancang produk instrument penilaian sikap sosial aspek tanggung jawab pada Tema 7 "Indahnya Keragaman di Negeriku" Subtema 1 "Keragaman Suku Bangsa dan Agama di Negeriku" Pembelajaran 3. Pada penelitian ini telah mengkaji buku guru terlebih dahulu. Pada Tema 7 "Indahnya Keragaman di Negeriku" Subtema 1 "Keragaman Suku Bangsa dan Agama di Negeriku" Pembelajaran 3 hanya terdapat penilaian ranah pengetahuan dan keterampilan, sedangkan penilaian ranah sikap tidak ada. Oleh karena itu, memutuskan untuk melakukan pengembangan instrument penilaian sikap sosial khususnya pada aspek tanggung jawab. Setelah mengakaji silabus dan penyusunan RPP, mulai menyusun produk berupa instrument penilaian sikap sosial aspek tanggung jawab. Dalam penyusunan RPP tematik terpadu, dilakukan dengan merancang langkah-langkah pembelajaran, menentukan materi pembelajaran, pendekatan, model, dan menyusun evaluasi. Evaluasi dirancang dengan menyusun kisi-kisi instrument penilaian sikap sosial aspek tanggung jawab pembelajaran tematik terpadu kelas 4 tema 7 Indahnya Keragaman di Negeriku subtema 1 Keragaman Suku Bangsa dan Agama di Negeriku semester 2 yang disajikan melalui tabel 3 sebagai berikut: 
Tabel 3. Kisi-kisi Instrumen Sikap Sosial Pembelajaran Tematik Terpadu Kelas 4

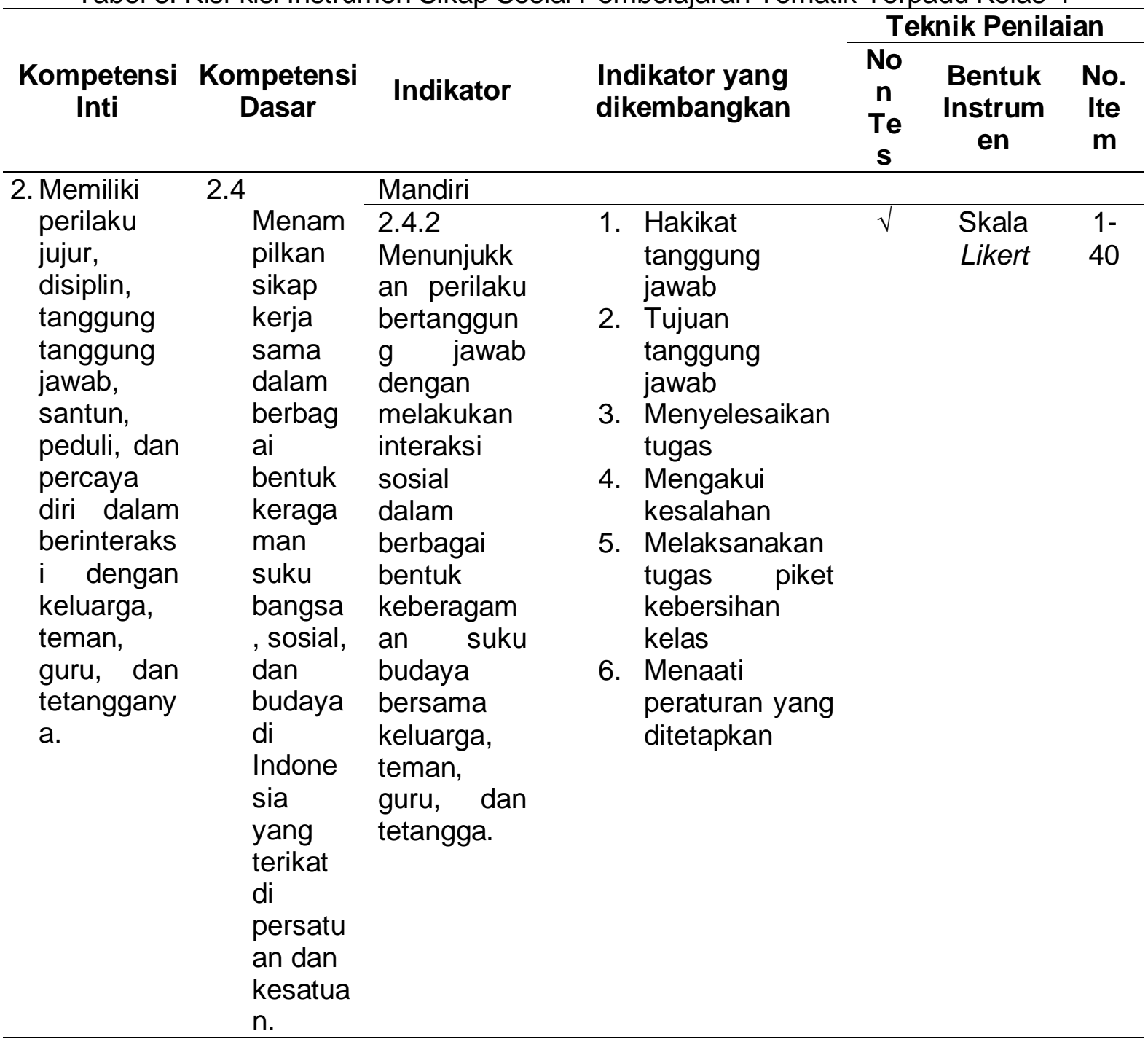

Sumber: Buku Panduan Penilaian Sekolah Dasar (2016)

\section{Development (Pengembangan)}

Tahap ini peneliti mengambangkan instrumen penilaian sikap sosial aspek tanggung jawab pada butir-butir pernyataan menggunakan Skala Likert kedalam angket sesuai dengan indikator yang akan dikembangkan. Pengembangan instrument penilaian sikap sosial aspek tanggung jawab ini, disusun ke dalam 40 butir pernyataan. Produk instrument penilaian sikap sosial yang dikembangkan terdiri dari 20 pernyataan favorable dan 20 pernyataan unfavorable. Instrumen penilaian sikap sosial aspek tanggung jawab disusun berdasarkan 9 indikator yang dikembangkan melalui buku Panduan Penilaian untuk Sekolah Dasar. Berikut adalah tabel pernyataan yang telah disusun dalam tabel 4 .

Tabel 4. Instrumen Penilaian Sikap Sosial Aspek Tanggung Jawab Peserta Didik Pembelajaran Tematik Terpadu Siswa Kelas 4 SD Tahun Pelajaran 2021/2022

\footnotetext{
No Pernyataan

1. Tanggung jawab peserta didik hakikatnya adalah menerima akibat dari perbuatan yang telah dilakukan.

2. Tanggung jawab akan menghambat perilaku peserta didik dalam kehidupan sehari-hari karena terlalu banyak memikirkan akibatnya.

3. Tanggung jawab bertujuan agar dapat melatih daya juang peserta didik dan tercipta kondisi selalu bertanggung jawab atas semua perbuatan yang telah dilakukan.
} 


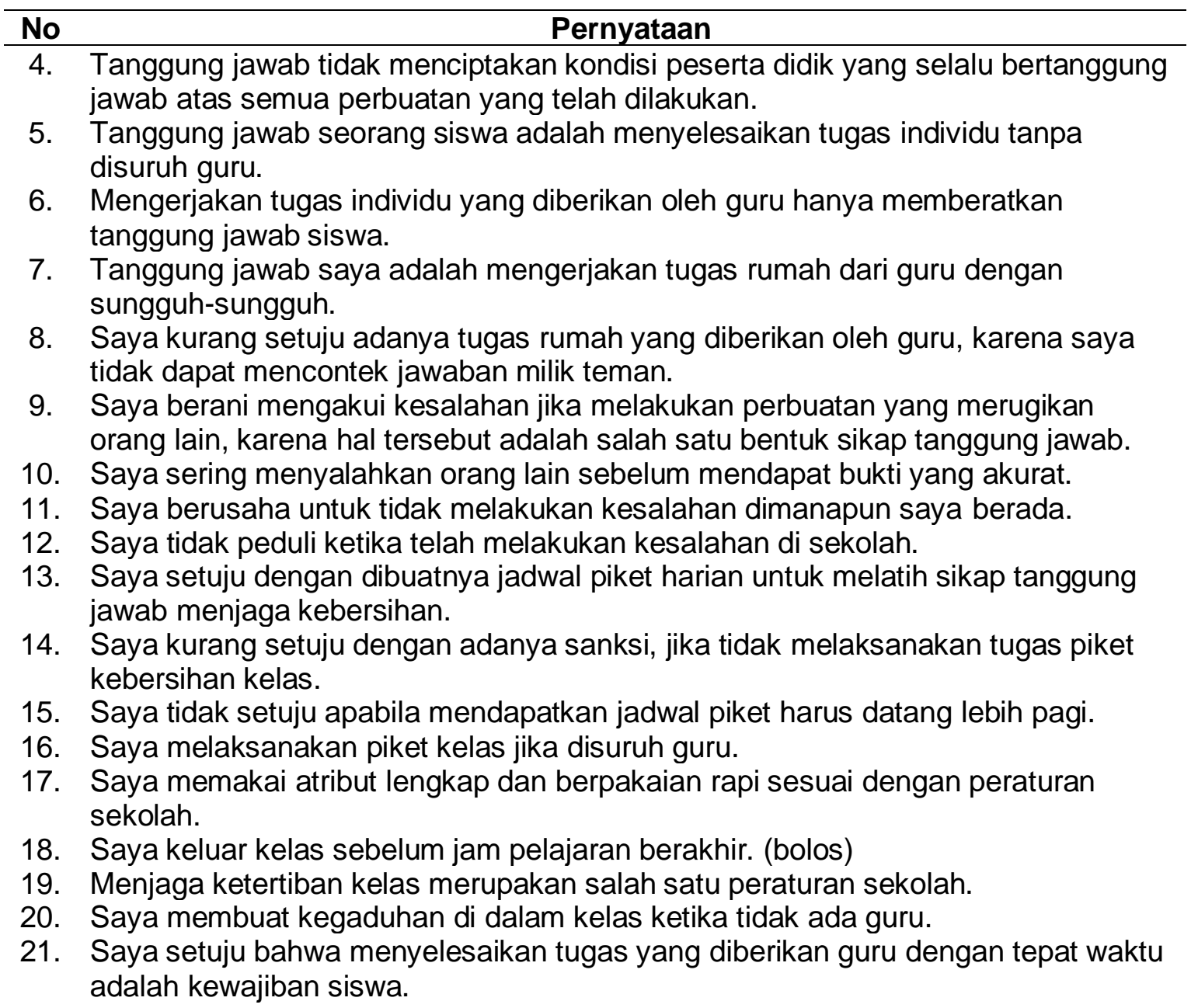

22. Saya tidak memperhatikan pengumuman dari guru terkait dengan tugas yang diberikan.

23. Saya bertanya kepada guru ketika belum paham mengenai tugas yang diberikan.

24. Saya tidak mengerjakan tugas dari guru karena belum paham.

25. Saya mencari solusi untuk memecahkan masalah dari pada menyalahkan orang lain.

26. Saya suka menyalahkan orang lain sebelum mendapat bukti yang akurat.

27. Berani mengakui kesalahan adalah salah satu bentuk tanggung jawab.

28. Saya selalu menghindar ketika telah melakukan perbuatan yang merugikan orang lain.

29. Ketika saya menjadi pengurus organisasi di kelas saya berusaha untuk bertanggung jawab.

30. Saya mendukung adanya struktur organisasi pengurus kelas karena dapat melatih sikap tanggung jawab.

31. Saya selalu mengikuti kegiatan kerja bakti membersihkan lingkungan sekolah karena dapat memperkuat sikap tanggung jawab dalam menjaga lingkungan alam.

32. Saya tidak setuju jika diadakannya kegiatan kerja bakti disekolahan karena sudah ada tukang kebun.

33. Mengerjakan tugas kelompok bukan merupakan tanggung jawab saya karena masih ada teman yang lain.

34. Saya ikut mengerjakan tugas kelompok tanpa pilih-pilih teman.

35. Saya setuju apabila teman yang tidak mengikuti kegiatan belajar kelompok dengan sungguh-sungguh harus ditegur.

36. Saya kurang setuju mendengarkan pendapat teman kelompok saat diskusi, 


\begin{tabular}{ll}
\hline No & \multicolumn{1}{c}{ Pernyataan } \\
\hline 37. & $\begin{array}{l}\text { karena membosankan. } \\
\text { baik. }\end{array}$ \\
38. & $\begin{array}{l}\text { Ketika saya merusakkan barang milik orang lain, saya tidak akan meminta maaf } \\
\text { dan menggantinya. }\end{array}$ \\
39. Saya setuju apabila diberi barang oleh orang lain harus dirawat baik. \\
40. $\begin{array}{l}\text { Mengembalikan barang yang dipinjam dari perpustakaan, bukan merupakan } \\
\text { tanggung jawab siswa. }\end{array}$
\end{tabular}

Instrumen penilaian sikap sosial yang telah disusun kemudian divalidasi oleh ahli, yaitu ahli penilaian, ahli materi, dan ahli Bahasa. Masukan-masukan dan saran yang diberikan oleh para ahli digunakan untuk merevisi dan memperbaiki butir-butir pernyataan dalam instrument penilaian tersebut. Hasil uji pakar ditunjukkan pada tabel 5 berikut.

Tabel 5. Hasil Uji Pakar Instrumen Penilaian Sikap Sosial Aspek Tanggung Jawab

\begin{tabular}{cccccc}
\hline No. & Ahli/Pakar & Skor Ideal & Skor Aktual & AP $(\%)$ & Kategori \\
\hline 1. & Ahli Penilaian & 56 & 45 & $80 \%$ & Sangat Baik \\
2. & Ahli Materi & 36 & 31 & $86 \%$ & Sangat Baik \\
3. & Ahli Bahasa & 48 & 46 & $95 \%$ & Sangat Baik \\
\hline
\end{tabular}

Berdasarkan dari tabel di atas, dapat disimpulkan bahwa hasil dari uji validasi ahli penilaian diperoleh skor 45 dari total skor 56 dengan presentasi sebesar $80 \%$ yang berarti termasuk kategori tinggi, uji validasi ahli Bahasa diperoleh skor 46 dari total skor 48 dengan presentase sebesar $96 \%$ yang berarti termasuk dalam kategori sangat tinggi, uji validasi ahli materi diperoleh skor 31 dari total skor 36 dengan presentase sebesar $86 \%$ yang berarti termasuk dalam kategori sangat tinggi. Dari hasil uji validasi ahli instrument penilaian sikap sosial aspek tanggung jawab layak untuk diujicobakan kepada peserta didik. Uji coba dilaksanakan di tiga SD dengan jumlah peserta didik yang berbeda. SD Negeri Pringapus 02 dengan jumlah peserta didik 5 orang, SD Negeri Pringapus 03 berjumlah 5 peserta didik, dan SD Negeri Sambirejo berjumlah 5 peserta didik.

\section{Implementation (Tahap Implementasi)}

Dari uji coba terbatas didapatkan bahwa dari 40 butir pernyataan yang diuji cobakan, 12 (30\%) butir pernyataan memiliki tingkat validitas sangat tinggi, 14 (35\%) butir pernyataan memiliki tingkat validitas tinggi, 12 (32,5\%) butir pernyataan memiliki tingkat validitas cukup, $1(27,5 \%)$ butir pernyataan memiliki tingkat validitas rendah. Dari hasil uji terbatas didapatkan $r_{\text {hitung }}$ terendah sebesar 0,164 yang berada pada rentang 0,21-0,40 dengan kategori validitas rendah. Sedangkan $r_{\text {hitung }}$ tertinggi sebesar 0,905 yang berada pada rentang 0,81-1,00 dengan kategori validitas sangat tinggi. Hasil penelitian menunjukkan rata-rata $r_{\text {hitung }}$ sebesar $0,671 \geq 0,20$ maka instrumen dinyatakan valid. Sedangkan reliabilitas pada uji terbatas diperoleh $\alpha$ sebesar 0.970 dengan kriteria sangat reliabel.

\section{Evaluation (Tahap Evaluasi)}

Pada tahap terakhir yaitu tahap evaluasi, melakukan analisis dan memperbaiki atau revisi pada produk yang sudah divalidasi oleh ahli dan produk yang sudah diujicobakan. Berdasarkan hasil uji coba terbatas diketahui bahwa masih ada 5 butir instrument penilaian sikap sosial yang tidak valid, sehingga harus diperbaiki.

\section{Pembahasan}

Hasil penelitian dan pengembangan yang dilakukan menunjukkan bahwa 40 butir pernyataan untuk penilaian sikap social valid dengan 5 butir pernyataan harus diperbaiki. Hasil ini tentunya tidak terlepas dari tahap-tahap pengembangan instrument penilaian. 
Dalam tahap pengembangan instrumen ada bebarapa tahap yang dilakukan yaitu tahap analisis kurikulum (analisis KD, Indikator dan materi), tahap pembuatan kisi-kisi instrument yang disesauikan dengan instrument penilaian yang dilakukan, tahap pembuatan instrument yang disesauikan dengan indicator-indikator yang dikembangkan. Tahap pembuatan ini tentunya harus memperhatikan karakteritik subjek yang akan dinilai. Dengan memperhatikan langkah-langkah pengembangan instrument tersebut akan mampu mengembangakan instrument penilian yang baik. Dengan instrument penilaian yang layak digunakan tentunya akan mempengaruhi bagaimana penilaian itu dilakukan dan akan memberikan gambaran yang yang sesaui dengan kondisi yang dinilai. Penilian akan membantu guru mengetahui perkembangan dan ketercapain pembelajaran. Efektifitas pembelajaran dipengaruhi oleh bagaimana penilaian yang dilakukan, dengan adanya hasil penilaian dari proses pembelajaran pendidik akan mampu mengelola pembelajaran dengan baik (Msosa et al., 2021; Tridane et al., 2015; Uttl, B., White \& Gonzalez, 2017). Penilaian akan memberikan pilihan kepada peserta didik untuk belajar atau tidak belajar (Saenz \& Smith, 2018). Dengan kata lain, adanya assessment yang dilakukan oleh pengajar akan berdampak terhadap siswa karena memberikan umpan balik dari apa yang sudah dibelajari oleh siswa (Granberg et al., 2021). Assessment dalam pembelajaran bukan alat yang digunakan untuk menaikkan nilai peserta didik, tetapi lebih kepada membekali peserta didik dengan pengetahuan yang dapat digunakan secara aktif untuk menyelesaikan masalah atau tugas diberikan (Black \& Wiliam, 2018; Leong et al., 2018). Salah satu penilaian yang dilakukan adalah penilian sikap. Penilaian sikap berhubungan dengan sikap siswa terhadap materi pelajaran, sikap siswa terhadap guru/pengajar, sikap siswa terhadap proses pembelajaran, dan sikap yang berkaitan dengan nilai atau norma yang berhubungan dengan materi pembelajaran (Ulfa, 2019).

Beberapa penelitian yang sudah dilakukan berkaitan dengan pengembangan instrument sikap adalah penelitian yang dilakukan oleh Wicaksono et al., (2016) menghasilkan instrumen penilaian sikap dengan teknik observasi, self assessment, dan peer assessment yang valid dan reliabel digunakan. Muslimah et al., (2017) menghasilkan instrumen penilaian sikap berupa rubrik penilaian sikap sosial pada outdoor learning yang layak digunakan setelah dilakukan uji validas, reliabitas, uji kelayakan dan uji coba. Astalini \& Kurniawan, (2019) menghasilkan instrument penilan sikap siswa terhadap mata pelajaran IPA yang valid dan reliabel.

Jadi, Instrumen penilaian sikap sosial telah memenuhi kriteria kelayakan yang memiliki butir pernyataan valid sehingga dapat digunakan untuk mengukur aspek tanggung jawab siswa. Berdasarkan dari hasil uji terbatas terhadap 15 siswa berasal dari 3 sekolah yang berbeda, didapatkan hasil bahwa pernyataan dalam instrument penilaian sikap sosial aspek tanggung jawab memiliki validitas dan reliabilitas tinggi sehingga layak untuk digunakan. Kelebihan dari penelitian ini adalah dapat menghasilkan produk berupa instrument penilaian sikap sosial aspek tanggung jawab yang valid dan reliabel, sehingga dapat membantu guru untuk menilai tanggung jawab siswa. Kekurangan penelitian ini adalah tidak dilakukannya uji coba lapangan lebih luas dikarenakan adanya pandemic covd-19, sehingga hanya dapat dilaksanakan sampai tahap uji terbatas dengan menggunakan 15 sampel dari 3 sekolah yang berbeda.

\section{Simpulan}

Instrumen penilaian sikap sosial telah memenuhi kriteria kelayakan yang memiliki butir pernyataan valid sehingga dapat digunakan untuk mengukur aspek tanggung jawab siswa. Berdasarkan dari hasil uji terbatas terhadap 15 siswa berasal dari 3 sekolah yang berbeda, didapatkan hasil bahwa pernyataan dalam instrument penilaian sikap sosial aspek tanggungjawab memiliki validitas dan reliabilitas tinggi sehingga layak untuk digunakans. 


\section{Daftar Pustaka}

Astalini, A., \& Kurniawan, D. A. (2019). Pengembangan Instrumen Sikap Siswa Sekolah Menengah Pertama Terhadap Mata Pelajaran Ipa. Jurnal Pendidikan Sains (Jps), 7(1), 1. https://doi.org/10.26714/jps.7.1.2019.1-7

Black, P., \& Wiliam, D. (2018). Classroom assessment and pedagogy. Assessment in Education: Principles, Policy and Practice, 25(6), 551-575. https://doi.org/10.1080/0969594X.2018.1441807

Carpenter, S. K., Witherby, A. E., \& Tauber, S. K. (2020). On Students' (Mis)judgments of Learning and Teaching Effectiveness. Journal of Applied Research in Memory and Cognition, 9(2), 137-151. https://doi.org/10.1016/j.jarmac.2019.12.009

Delita, F. (2017). Penerapan Authentic Assesment Pada Mata Kuliah IPS Terpadu Semester Gasal Tahun Ajaran 2016/2017. Jurnal Geografi, 9(2), 133. https://doi.org/10.24114/jg.v9i2.6970

Granberg, C., Palm, T., \& Palmberg, B. (2021). A case study of a formative assessment practice and the effects on students' self-regulated learning. Studies in Educational Evaluation, 68(August 2020). https://doi.org/10.1016/j.stueduc.2020.100955

Kartowagiran, B., \& Jaedun, A. (2016). Model asesmen autentik untuk menilai hasil belajar siswa sekolah menengah pertama (SMP): implementasi asesmen autentik di SMP. Jurnal Penelitian Dan Evaluasi Pendidikan, 20(2), 131-141. https://doi.org/10.21831/pep.v20i2.10063

Leong, W. S., Ismail, H., Costa, J. S., \& Tan, H. B. (2018). Studies in Educational Evaluation Assessment for learning research in East Asian countries. Studies in Educational Evaluation, 59(September), 270-277. https://doi.org/10.1016/j.stueduc.2018.09.005

Machts, N., Zitzmann, S., \& Möller, J. (2020). Dimensionality of teacher judgments on a competency-based report card in elementary school. Learning and Instruction, 67(March), 101328. https://doi.org/10.1016/j.learninstruc.2020.101328

Msosa, A., Bruce, J., \& Crouch, R. (2021). Effect of a formative assessment intervention on nursing skills laboratory learning in a resource-constrained country. Nurse

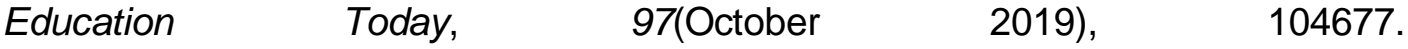
https://doi.org/10.1016/j.nedt.2020.104677

Muslimah, I., Nugraha, A., \& Hamdu, G. (2017). Pengembangan Instrumen Penilaian Sikap Sosial pada Outdoor Learning di Sekolah Dasar. PEDADIDAKTIKA: Jurnal IImiah Pendidikan Guru Sekolah Dasar, 4(2), 158-168. https://ejournal.upi.edu/index.php/pedadidaktika/article/view/7204/8041

Riscaputantri, A., \& Wening, S. (2018). Pengembangan instrumen penilaian afektif siswa kelas IV sekolah dasar di Kabupaten Klaten. Jurnal Penelitian Dan Evaluasi Pendidikan, 22(2), 231-242. https://doi.org/10.21831/pep.v22i2.16885

Sa'adah, E. N. L., \& Sigit, D. (2018). Pengembangan Instrumen Penilaian Sikap dan Keterampilan Psikomotorik pada Materi Elektrokimia. Jurnal Pendidikan: Teori, Penelitian, Dan Pengembangan, 3(8), 1023-1026. http://journal.um.ac.id/index.php/jptpp/article/view/11405/5413

Saenz, G. D., \& Smith, S. M. (2018). Testing Judgments of Learning in New Contexts to Reduce Confidence. Journal of Applied Research in Memory and Cognition, 7(4), 540-551. https://doi.org/10.1016/j.jarmac.2018.07.003

Tridane, M., Belaaouad, S., Benmokhtar, S., Gourja, B., \& Radid, M. (2015). The Impact of Formative Assessment on the Learning Process and the Unreliability of the Mark for the Summative Evaluation. Procedia - Social and Behavioral Sciences, 197(February), 680-685. https://doi.org/10.1016/j.sbspro.2015.07.058 
Ulfa, I. R. (2019). Implementasi Instrumen Penilaian Sikap di SDN Gunungsaren Bantul. Palapa, 7(2), 251-266. https://doi.org/10.36088/palapa.v7i2.357

Uttl, B., White, C. A., \& Gonzalez, D. W. (2017). Meta-analysis of faculty's teaching effectiveness: Student evaluation of teaching ratings and student learning are not related. Studies in Educational Evaluation, 51, 22-42.

Wicaksono, T. P., Muhardjito, \& Harsiati, T. (2016). Pengembangan penilaian sikap dengan teknik observasi, self assessment, dan peer assessment pada pembelajaran tematik kelas V SDN Arjowinangun 02 Malang. Jurnal Pendidikan: Teori, Penelitian, Dan Pengembangan, 1(1), 45-51. http://journal.um.ac.id/index.php/jptpp/article/view/5214 